\title{
О каменных пляжах Мурманского побережья Баренцева моря
}

\author{
Нерадовский Ю.Н., Мирошникова Я.А., Компанченко А.А. \\ Геологический институт КНЦ РАН, Anamumbl, miroshnikova@geoksc.apatity.ru
}

Аннотация. В статье рассмотрено строение и образование каменных (валунно-галечных) пляжей Мурманского побережья Баренцева моря. Борта и ложе каньонов сложены породами красного цвета. В пределах каньона можно условно выделить пляж (приливная и прибойная зоны) и две террасы. Валунно-галечный материал пляжей, располагающихся на ложе каньонов, сложен в основном светлыми породами. Примечательной особенностью каменных пляжей является развитие валунно-галечного материала с высокой степенью окатанности, что привело к образованию необычной гальки, форма которой близка к идеальной геометрии яйца. Вероятно, причиной образования уникальных каменных пляжей на Мурманском побережье стала геологическая обстановка данной территории - поднятие Балтийского щита, разрушение более древних пород и истирание их о более молодые породы.

Ключевые слова: Мурманское побережье, валунно-галечные пляжи, каньон, колодцы, траншеи, котлы, гроты, галька.

\section{On stone beaches of the Murmansk coast of the Barents Sea}

\author{
Neradovsky Yu.N., Miroshnikova Ya.A., Kompanchenko A.A. \\ Geological Institute, KSC RAS, Apatity, \\ miroshnikova@geoksc.apatity.ru
}

\begin{abstract}
The article considers the structure and formation of stone (boulder-pebble) beaches of the Murmansk coast of the Barents Sea. The walls and the bed of the canyons are composed of red rocks. Within the canyon you can provisionally identify the beach (tidal and surf zones) and two terraces. Boulder-pebble material of the beaches located on the bed of the canyons is mainly composed of light rocks. A remarkable feature of the stone beaches is the development of boulder-pebble material with a high degree of roundness, which led to the formation of unusual pebbles, the shape of which is close to the ideal geometry of an egg. The reason for the formation of unique stone beaches on the Murmansk coast might be the geological setting of the area, i.e. uplift of the Baltic shield, destruction of older rocks and their abrasion on younger rocks.
\end{abstract}

Key words: Murmansk coast, boulder-pebble beaches, canyon, wells, trenches, pot-holes, grottoes, pebbles.

\section{Введение}

Удивительные по своей красоте и образованию каменные пляжи обнаружены на Мурманском побережье Баренцева моря, расположенном на юге Кольского полуострова. Примечательной особенностью пляжей является широкое развитие валунно-галечного материала с высокой степенью окатанности валунов и гальки. Особенно многочисленны каменные пляжи на участке от острова Малый Олений до острова Малый Зеленецкий. Здесь на расстоянии около 40 км расположено более 70 пляжей, из них 15 находятся в районе села Териберка. Такие пляжи до сих пор мало изучены, и их образование вызывает большой научный интерес.

В основу данной статьи лёг новый материал, основанный на изучении топографических карт и космических снимков 70 валунно-галечных пляжей и на визуальном обследовании 11 пляжей в районе села Териберка. В результате были собраны данные о строении белокаменных пляжей Мурманского побережья и об их валунно-галечном материале. Исследования проведены без применения инструментальной съемки и носят предварительный характер.

\section{Геологическое строение района}

В районе села Териберка обнажаются породы Териберско-Вороньинского блока Мурманского домена (Козлов и др., 2006). Мурманский домен является самым древним образованием Балтийского кристаллического щита. На 80 \% он сложен тоналитами, плагиогранитами, диоритплагиогранитами с возрастом 3100 млн. лет, которые прорываются более молодыми глубинными 
породами - эндербитами - с возрастом 2830-2790 млн. лет и красными калиевыми гранитами с возрастом 2750-2600 млн. лет (Ветрин, 1979; Козлов и др., 2006; Петровский и др., 2008). Все породы Мурманского домена пересекаются дайками протерозойского и более молодого возраста (Арзамасцев и др., 2009).

Начиная с позднего протерозоя (около 1600 млн. лет назад), Балтийский щит постоянно поднимался, что сопровождалось непрерывным разрушением (выветриванием) горных пород под воздействием экзогенных процессов, приводивших к понижению рельефа (Докембрийская тектоника..., 1992). Это, в свою очередь, компенсировалось новым подъемом. В результате на поверхности постепенно оказались глубинные, сложно преобразованные породы докембрийского (архейского и протерозойского) возраста (Эндогенные режимы...,1991). Наиболее обширные площади выходов калиевых гранитов и эндербитов наблюдаются в Териберско-Вороньинском сегменте.

\section{Элементы рельефа, связанные с каменными пляжами Мурманского побережья}

Благодаря непрерывному разрушению древних пород фундамента Балтийского щита и действию морских волн, берег Баренцева моря в Териберском районе имеет извилистые формы и изобилует каньонами. Каньоны представляют собой корытообразные углубления в береговой части моря. Каждый каньон имеет борта и ложе, сложенные красными породами, вероятно калиевыми гранитами и эндербитами. Борта каньонов обточены и сглажены. В пределах каньонов можно условно выделить две террасы и валунно-галечный пляж (Сафьянов, 1996), сложенный в основном породами белого цвета. В пределах всех каменных пляжей можно выделить прибойную и приливную зоны.

Начало первой террасы отмечено штормовым валом галечника и плавника на высоте 7-10 м над уровнем моря. Терраса полого поднимается вверх на расстояние около 200 м, где заканчивается

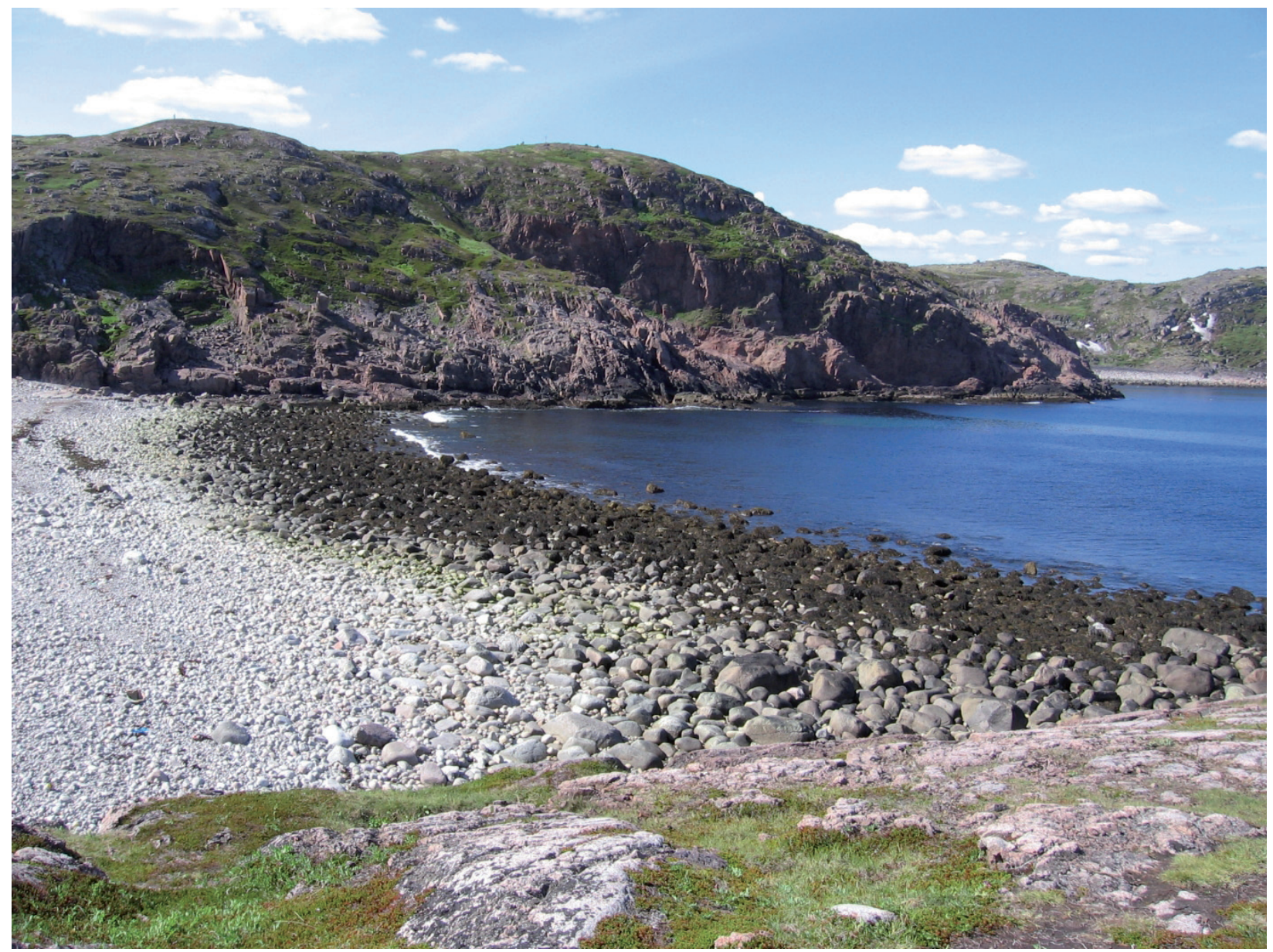

Рис. 1. Фото пляжа № 7 (темное - приливная зона, светлое - прибойная зона).

Fig. 1. Photo of the beach No. 7 (dark - tidal zone, light - surf zone). 
валом второй более древней террасы на высоте 40-45 м. Первая терраса сложена хорошо окатанным галечником, но галька покрыты лишайником и от этого имеет серый цвет. Вторая терраса сложена плохо окатанным галечником и глыбами (галечно-глыбовая). Породы, слагающие галечник и глыбы террас аналогичны породам слагающим пляж и будут описаны далее. Выше второй террасы на высоте 70-110 м над уровнем моря наблюдаются многочисленные глыбы светло-серых пород (предположительно, плагиогранитов), лежащие на красных породах. Предполагается, что они представляют собой останцы разрушения древних гранитов, которыми сложена галька пляжей.

Прибойная зона начинается от вала на границе с первой террасой и опускается полого вниз до верхней кромки приливной зоны (рис. 1). Ширина прибойной зоны от линии прилива до краевого вала первой террасы разная: в губах ширина зоны иногда составляет всего 30 м, а на открытых к морю берегах - обычно 50-70 м. Протяженность прибойной зоны вдоль берега моря контролируется шириной каньонов. Эта верхняя часть пляжа сформирована под воздействием крупных штормовых волн. Она является главным участком белокаменных пляжей, где образуются идеально окатанные яйцевидные гальки, описанные далее.

Приливная зона слагает нижнюю часть пляжа, она периодически обнажается в отлив и покрывается водой в прилив (рис. 1). Средняя высота приливов в районе села Териберка составляет 4 м, максимальная высота достигает 6 м. В зависимости от наклона ширина приливной зоны незначительно колеблется - от 50 до 70 м. Протяженность вдоль береговой линии широко варьирует в зависимости от ширины каньона - от 50 м до 1 км. Галька и валуны в этой зоне покрыты морскими водорослями. В приливной зоне, как правило, заканчивается галечник. На некоторых пляжах в этой зоне наблюдаются развалы и останцы коренных пород, что свидетельствует об окончании галечного пляжа.

Благодаря незамерзающему Баренцевому морю работа волн происходит круглый год. В спокойном состоянии моря волны воздействуют только на нижнюю часть прибойной зоны. Под постоянным воздействием волн здесь происходит активная абразивная деятельность, перемещение и окатывание валунов. В этой части пляжа валуны крупнее, наблюдаются весьма крупные экземпляры размером до 2 м. Для перемещения таких гигантов обычных приливных волн недостаточно и используется могучая энергия штормовых волн. Высота штормовых волн на побережье Баренцева моря может достигать 10 м. Деятельность морских волн обеспечивает активное взаимодействие валунно-галечного материала с породами, образующими ложе каньонов. В результате в приливной зоне наблюдаются многочисленные выбоины (рис. 2 А), котлы, колодцы и траншеи, последние могут присутствовать и в прибойной зоне.

Koтль - углубления разного размера и округлые ямки, покрывающие большие площади поверхности ложа гранитов. Котлы образуются в результате ударно-вращательной эродирующей деятельности гальки о красные породы и выноса разрушенного материала. Учитывая большое количество котлов можно полагать, что многие гальки прошли такую стадию обтачивания о граниты.

Колодиы - глубокие круглые ямы (рис. 2 Б). Размеры колодцев достигают 1-2 м в диаметре и до 1.5 м глубиной. Горло колодцев в основном овальное или круглое. Стенки колодца всегда препарированы галечным материалом, а на дне колодца находятся единичные хорошо окатанные гальки. Происхождение колодцев связано с длительным воздействием галек на красные породы. Предположительно группа галек по каким-то причинам сосредоточилась в углублении и под действием волн выбила колодец, при этом большая часть галек не сохранилась, а на дне остались лишь единичные экземпляры. Колодцы могут переходить в траншеи.

Транщеи - удлиненные выемки в породах основания (рис. 2 В). Удлинение траншей всегда направлено в сторону моря. Траншеи представляют собой канавы, у которых есть «голова» и «хвост». Голова траншеи обращена в берег, а хвост - в море. В траншее всегда находится россыпь галек. Обычно они сосредоточены в голове, реже рассеянны по траншее. Стенки и подошва траншеи препарированы галечником и гладкие, этим они отличаются от простых трещин. Траншеи располагаются в основном в нижней части прибойной зоны пляжа и переходят в зону прилива, редко находятся полностью в зоне прибоя. Размеры траншей составляют первые метры по ширине и глу- 

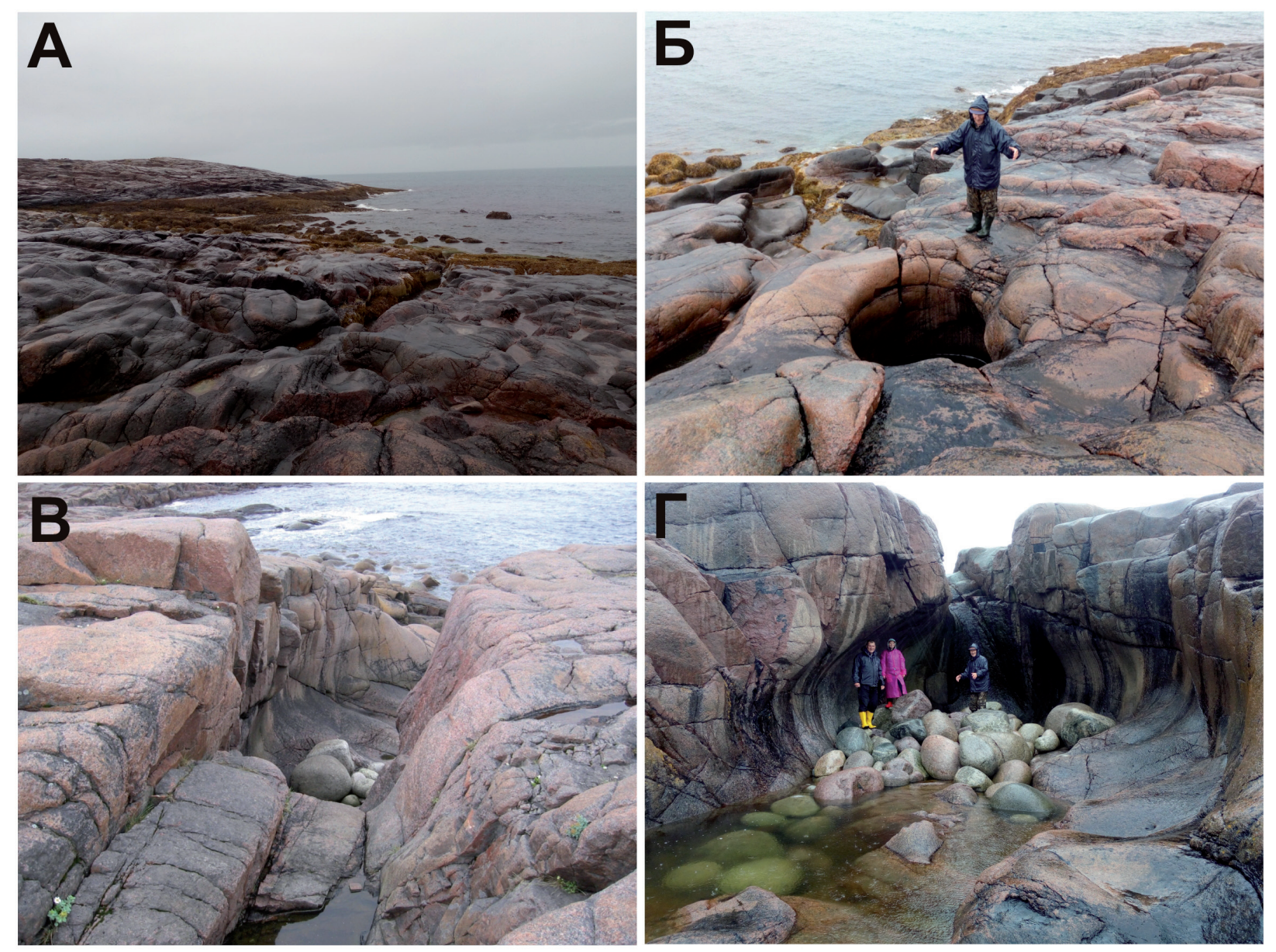

Рис. 2. Формы рельефа, возникающие в результате воздействия галечника на коренные породы: А - выбоины, Б - колодец, В - траншея, Г - грот.

Fig. 2. Landforms resulting from the impact of pebbles on the bedrock: A - hollow, $\mathrm{B}-$ well, $\mathrm{B}-$ trench, $\Gamma-\mathrm{grotto}$.

бине и десятки метров по длине. Образование траншей связано с ударным действием галечника на дно и стенки трещины в периоды действия штормовых волн и перекатыванием гальки по траншеи.

Гроты относятся к разновидности траншей крупного размера. Строение гротов аналогично траншеям, но в головной части у них образована глубокая округлая ниша со сводом. Один из гротов на пляже № 5 представляет собой траншею длиной около 25 м, глубиной 4-5 м и шириной 5-7 м (рис. 2 Г). В голове траншеи находится полукруглая пещера с вогнутыми стенами, над которой образован сводчатый выход вверх и расширяющийся выход в сторону моря. В головной и в средней части пещеры располагается груда хорошо окатанных валунов и крупной гальки. Дно грота покрыто котлами, в которых находятся окатанные валуны.

\section{Валунно-галечные образования каменных пляжей}

Валунно-галечный материал на белокаменных пляжах заметно контрастирует с красными породами каньонов. Эти образования представляют собой обломки более светлых пород, вероятно, представленных в основном плагиогранитами, гнейсогранитами, тоналитами и диоритплагиогранитами. Размеры галек 10-20 см, размер валунов колеблется от 20 до 200 см.

Валунно-галечные образования имеют разную степень окатанности. Удивительно то, что более проработанные и идеально окатанные валуны и галька на всех пляжах имеют форму яйца (рис. 3). На некоторых пляжах около 30 \% валунно-галечного материала сложено подобными образованиями. Размеры яйцевидной гальки варьируют от 10 см до 1 м, при этом форма остается близка к идеальной геометрии яйца (соотношение длинной и короткой оси 5:4 и 9:5). Такие формы гальки 
не зависят от того, каким типом пород она сложена. Дальнейшее более детальное изучение состава гальки позволит объяснить природу возникновения её яйцевидной формы.

\section{Заключение}

Каменные пляжи Мурманского побережья Баренцева моря наблюдаются в ложе каньонов. В пределах каньонов можно наблюдать две террасы и белокаменный пляж. Ложе и борта каньонов сложены красными породами, предположительно гранитами и эндербитами, тогда как белый галечно-валунный материал - предположительно гнейсогранитами, плагиогранитами и другими более древними породами. В приливной и прибойной зоне пляжей наблюдаются многочисленные следы воздействия гальки на ложе каньонов. К уникальным явлениям, на наш взгляд относится, способность валунов и гальки из пород Мурманского домена приобретать яйцевидную форму при окатывании под действием морских волн.

Наличие двух террас с различной высотой вала и с разной степенью окатанности валунно-галечного матери-

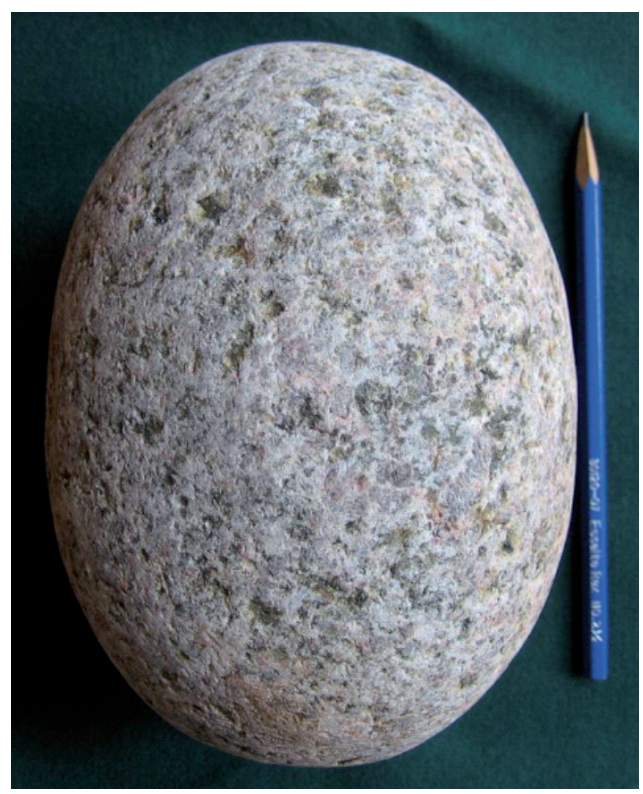

Рис. 3. Галька яйцевидной формы.

Fig. 3. Egg-shaped pebbles. ала согласуется с общепринятым мнением о том, что в послеледниковое время побережье Баренцева моря поднималось, но позже скорость его поднятия замедлилась (Корсакова, 2009). Вероятно, образование пляжей связано с разрушением пород Мурманского домена вследствие поднятия Балтийского щита в послеледниковое время и истиранием более хрупких, древних пород о более прочные, молодые породы.

\section{Литература}

1. Арзамасцев А.А., Федотов Ж.А., Арзамасцева Л.В. Дайковый магматизм северо-восточной части Балтийского щита. СПб. Изд-во: Наука. 2009. 383 с.

2. Ветрин В.Р. Древнейшие гранитоидные комплексы Мурманского кристаллического массива // Древнейшие гранитоиды Балтийского щита. Апатиты. Изд-во: КФАН СССР. 1979. С. 50-91.

3. Докембрийская тектоника северо-восточной части Балтийского щита (объяснительная записка к тектонической карте масштаба 1: 500 000). Авт.: Радченко А.Т., Балаганский В.В., Виноградов А.Н., Голионко Г.Б., Петров В.П., Пожиленко В.И., Радченко М.К. СПб. Изд-во: Наука. 1992. 112 с.

4. Козлов Н.Е., Сорохтин Н.О., Глазнев В.Н., Козлова Н.Е., Иванов А.А., Кудряшов Н.М., Мартынов Е.В., Тюремнов В.А., Матюшкин А.В., Осипенко Л.Г. Геология архея Балтийского щита. СПб. Изд-во: Наука. 2006. 329 c.

5. Корсакова О.П. Кольский полуостров в голоцене. Наука в России. № 6. 2009. С. 102-109.

6. Петровский М.Н., Петровская Л.С., Баянова Т.Б., Левкович Н.В. Эндербиты района Гремихи Мурманского архейского домена: U-Pb- и Sm-Nd- данные // ДАН. Т. 418. № 1. 2008. С. 90-94.

7. Сафьянов Г.А. Геоморфология морских берегов. М. Изд-во: МГУ им. М.В. Ломоносова. 1996. 400 с.

8. Эндогенные режимы и эволюция магматизма в раннем докембрии (на примере северо-восточной части Балтийского щита). СПб. Изд-во: Наука. 1991. 198 с. 